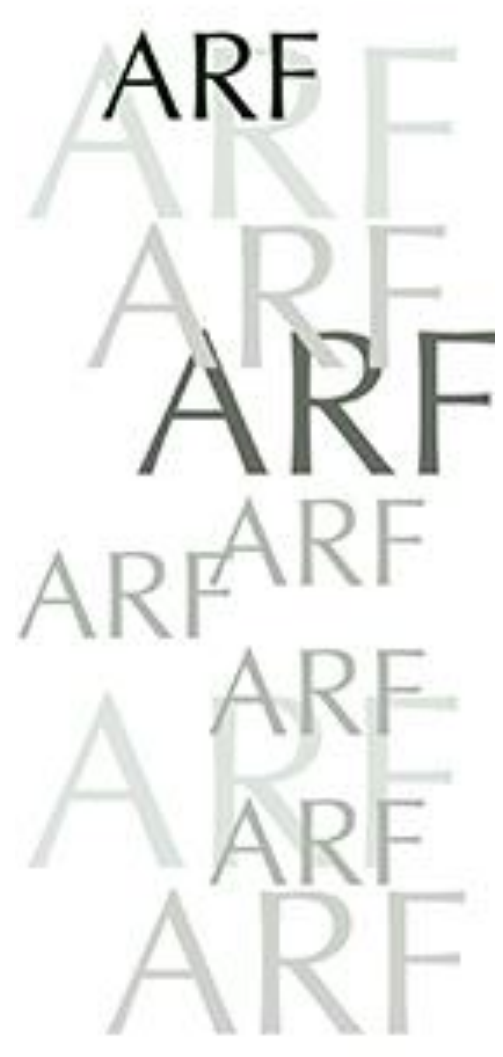

\title{
Timescapes beyond the Metropolises
}

\author{
Culture-led urban regeneration in Myllytulli, Oulu
}

\author{
Tiina Hotakainen \\ University of Oulu \\ Vienna University of Technology \\ tiina.hotakainen@gmail.com
}

\begin{abstract}
The past decades have witnessed a rise of culture-led urban regeneration. The successful cultural models have travelled throughout the world, and applied to cities and urban areas regardless of their size and location. Culture, ranging between high culture and contemporary creative economies, acquires potential to contribute to physical, social and economic aspects of urban regeneration. Successful examples of culture-led urban regeneration have tempted small cities to invest in traveling global cultural policies. Academic community has criticized these travelling policies for over-simplifying the abstract notion of culture, overrating the benefits of culture-led urban regeneration and ignoring local temporal specifics. This paper argues that a temporal analysis framework would enable a holistic approach to culture-led urban regeneration, and embrace the temporal uniqueness of urban contexts. This article discusses the temporal characteristics of culture-led regeneration in a provincial city context within an empirical case study analysis of Myllytulli in Oulu, Northern Finland. Myllytulli represents a district of regional cultural relevance where cultural amenities range from museums and educational facilities to creative bottom-up initiatives. This study reframes Myllytulli's urban regeneration process using temporal conceptions of recent interdisciplinary academic discourse. The empirical data set consists of expert interviews, observation material and municipal planning documents. The results analyse the urban regeneration process within the linear temporal ideals of rational-comprehensive planning, reactive experiential urbanism and relational dimensions of time. The paper suggests time-sensitive approaches for future research and practice of urban regeneration.
\end{abstract}

Keywords: Culture-led urban regeneration, temporal analysis framework, temporal context, temporal uniqueness, provincial cities 


\section{Introduction}

For the last 30 years, culture has acquired a fundamental role in dealing with globally relevant urban problems, which range from economic decay to social issues (Bianchini 1993, Garcia 2004, Miles \& Paddison 2005). The transition from industrial production to knowledge economy has placed culture in the very centre of urban development (Garnham 2005). Urban agglomerations have become centres of creative knowledge and cultural innovation, instead of their previous role as places of industry and manufacture (Garcia 2004). Culture-led urban regeneration as a concept originates in world metropolises and global cultural capitals (Evans 2002) but successful culture-led urban regeneration projects of smaller cities like Glasgow or Bilbao (Garcia 2004, Miles 2005) have encouraged small and intermediate cities to use culture for urban regeneration (Bell \& Jayne 2006).

\section{Urban agglomerations have become centers of creative knowledge and cultural innovation, instead of their previous role as places of industry and manufacture}

Despite the cultural successes of temporally unique cases, the traveling cultureled models for urban regeneration have posed problems. The global examples for culture-led urban regeneration are applied to cities irrespective of their size, location and demographics (Evans \& Foord, 2006), failing to respect the local values and characteristics (Evans 2009). This study addresses the local temporal uniqueness of a provincial city through a temporal framework analysis. The paper indicates the potential of temporal dimension for culture-led urban regeneration research and practice. This paper argues that a temporal dimension would help suitability application in unique urban contexts. The results evaluate culture-led urban regeneration process in a provincial city. The focus is on temporal effects, objectives and outcomes of culture-led urban regeneration of Myllytulli district in Oulu, Northern Finland. Myllytulli is an area of regional cultural importance, with its existing cultural and educational facilities, recreational green areas and architectural heritage. Oulu is currently bidding for the shared title of European Capital of Culture 2026, and culture comprehends urban policy from district regeneration to city-level strategies.

Urban regeneration is a comprehensive action of physical, social, economic and cultural enhancement of an area (Robert \& Sykes 2000). Culture emerged in municipal urban regeneration in the 1980s, represented via contemporary cultural elements such as media, design and tourism (Bianchini 1993, Evans 2002). Currently, culture-led regeneration encompasses not only cultural economies but also creative industries (Garnham 2005). This article discusses culture as Myllytulli's cultural amenities, ranging from municipal high culture and architectural heritage to local everyday cultures. Culture-led urban regeneration models represent globally traveling policies, and thus, this paper places them in the global context, discussing Oulu as a provincial city, as it represents a city of regional importance in northern Finland with about 200.000 inhabitants.

After a brief introduction in recent culture-led urban regeneration discourse, this article presents an empirical case study, illustrating the temporal perspective of a provincial city. The research question of this paper inquires 'How do the different temporal approaches in the culture-led urban urban regeneration affect the neighbourhood Myllytulli?' The study follows the conceptual triad of linear, experiential and relational to elaborate the temporal characteristics of Myllytulli's regeneration process. This article focuses on the key timeframe 2008-2018. The municipal culture-led urban regeneration project focused on Lasaretinväylä but the cultural clustering reaches around the district. The study includes urban regeneration initiatives in Myllytulli within the timeframe but excludes any projects or processes without reference to arts or culture. The case study is structured through three theoretical categories and their relative grounded theory founded empirical sub-categories. The concluding remarks discuss theoretical and practical implications, highlighting the key findings of this paper. 


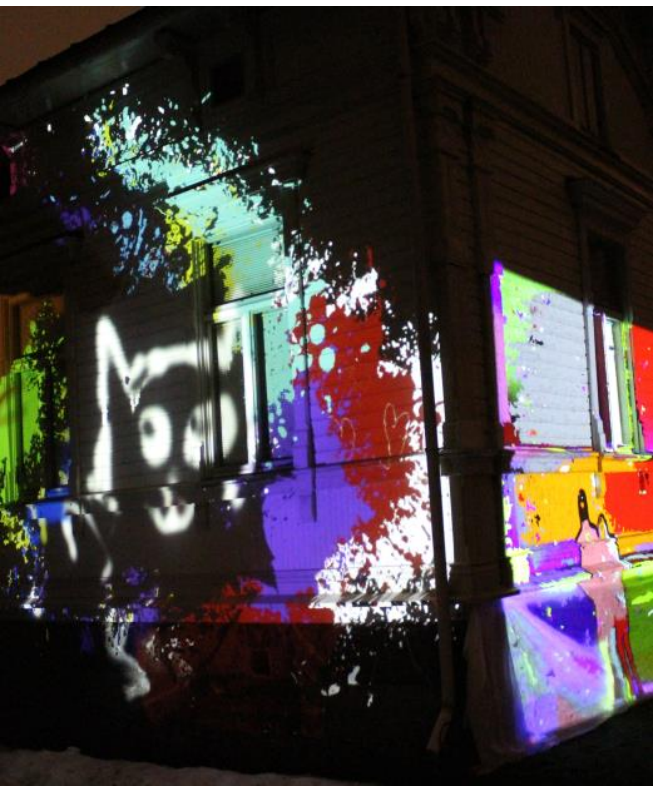

Image 1. Lumo Light Festival 2019 coloured up facades in Myllytulli. Photo source: author.

\section{Culture-led urban regeneration in provincial cities}

Due to the considerable economic risks, municipalities search safe and sterile solutions for urban regeneration. A copy-and-paste of cultural ideas from elsewhere has become popular as an urban strategy (Richards \& Wilson 2006). Through visible successes and encouraging examples, municipalities of any location and size have applied culture-led policies and strategies as direct models in different contexts. These traveling models neglect the temporal uniqueness of successful cases (Miles 2005). Culture-led urban regeneration seems an easy alternative (Miles 2006), making it appealing for small cities to think big and pursue global visibility. When entering the competition with large cultural metropolises, smaller cities' chances of success are quite restricted (Evans \& Foord 2006, Lysgård 2012). This article addresses the criticism by offering a temporal analysis framework for culture-led urban regeneration. Despite the criticism towards the traveling strategies (Zukin 1995, Peck 2005, Evans \& Foord, 2006, Lysgård 2012, 2016), a contextual application of culture-led urban regeneration has potential to improve the social and economic aspects, and to increase local empowerment (Bell \& Jayne 2006).

Metropolitan areas dominate culture-led urban regeneration research (Evans 2002) and create a bias in the academic discourse. Not only are small cities numerically the most common urban form globally (Bell \& Jayne 2009) but also recent studies have indicated that smaller or remote municipalities present a better environment for cultural and creative industries, when compared to world metropolises (Cho et al. 2018). In addition, distant location and smaller size protect municipalities against gentrification, providing long-term support to cultural actors (Andres 2013, Lehtovuori \& Ruoppila 2017).

\section{Temporal perspective in culture-led urban regeneration}

Temporality is present in culture-led urban regeneration processes for instance via distances (Henckel 2007), temporal features of the urban morphology (Herkommer 2007) and the usage patterns of cultural amenities (Montgomery 2003). The recent discourse has exposed the relevance of temporary uses (Lehtovuori \& Ruoppila 2017, Madanipour 2017) but otherwise the temporal aspect remains overlooked in urban regeneration research (Raco et al 2008, Henckel 2007) and even more so in culture-led urban regeneration (Deffner 2005). Provincial cities display a temporally and spatially specific environment. The concepts of temporal intensification and 24-hour-cities describe the temporality of metropolitan areas but scarcely populated environments require different theories and problem statements.

In order to inspect culture-led urban regeneration as the integrative action it is, this study includes temporal aspects outside the common permanent versus ephemeral dichotomy, as discussed between temporary uses and cultural heritage. The following chapter discusses a theoretical framework, which founds on interdisciplinary discourse on urban temporalities. Ali Madanipour's (2017) temporary urbanism and Monica Degen's (2018) temporalities of urban regeneration borrow the key time concepts for the temporal triad. Appointed neighbourhood elements of cultural quarters (Montgomery 2003, Lidegaard et al. 2018) demonstrate the appearance of temporal approaches in the empirical case study.

\section{Temporal analysis framework}

This chapter elaborates the theoretical triad of linear, experiential and relational approaches to culture-led urban regeneration (see table 1 for an overview). Linear temporality dominates spatial disciplines. This slow physical transformation leaves visible traces to the built environment, which reflects the 
size and history of the city. Permanent structures create a backbone for cultural activity: cultural buildings, such as libraries or museums, represent trademarks and express stability in the fast fluctuating societies (Lynch 1972). In order to plan the urban environment with blueprint drawings and linear schedules (Graham \& Healey 1999), linear temporality diminishes time to an instrument (Madanipour 2017). This rational and abstract thought represents the temporality of rationalcomprehensive urban planning. Urban morphology, public spaces and built heritage (Montgomery 2003, Rahbarianyazd \& Doratli 2017) represent the neighbourhood elements of built form and linear temporality. Culture flourishes in a diverse environment with buildings differing in function, size and age (Jacobs 1961), embracing the time layers of past decades. Heritage buildings improve the quality of public space by illustrating local history (Gehl 2011).

The acceleration of world-time, however, emphasises ephemerality rather than permanence, and attaches value to momentary experiences (Madanipour 2017). The 'experience economy' (Pine \& Gilmore 1998) represents this major shift from selling tangible goods to the current market for personal memories. Panu Lehtovuori (2010) claims a new urban planning paradigm, 'experiential approach to production of urban public space' within this temporal concept. 'Experiential time' embraces the present situation (Dodgshon 2008), the first-person perspective and the individual experience (Madanipour 2017). The role of environment is smaller than in linear regeneration processes. On one hand, the virtual technologies enable global experiences despite the location, where participants share their experiences via social media. On the other hand, strong individual experiences require personal presence in the specific time and place. Temporary uses and urban events, however short-term, may result in longer-term activities or initiate physical urban transformations. Temporary urbanism challenges traditional urban development modes and time concepts. Compared with new constructions, a re-use of existing structures releases potential capital for financing cultural activities. Temporary urbanism as an overarching debate ranges from bottom-up experiments and squatting to global mega events. This

Table 1. The three temporal concepts in relation to the neighbourhood elements. Source: author. paper includes temporary uses and cultural events (Richards \& Palmer 2010) in the neighbourhood elements.

\begin{tabular}{lll}
$\begin{array}{l}\text { Temporal } \\
\text { concept }\end{array}$ & Neighbourhood elements & Theoretical contributors \\
\hline Linear & $\begin{array}{l}\text { architectural heritage } \\
\text { urban morphology } \\
\text { public space }\end{array}$ & $\begin{array}{l}\text { Montgomery 2003, Gehl 2011, } \\
\text { Rahbarianyazd \& Doratli 2017 }\end{array}$ \\
\hline Experiential & $\begin{array}{l}\text { temporary uses } \\
\text { cultural events }\end{array}$ & Madanipour 2017, Lehtovuori 2010 \\
\hline \multirow{3}{*}{ Relational } & $\begin{array}{l}\text { evening economy } \\
\text { minor cultural activities } \\
\text { consumption possibilities } \\
\text { third places } \\
\text { cultural production } \\
\text { education providers }\end{array}$ & $\begin{array}{l}\text { Montgomery 1994, 2003; Madanipour } \\
\text { 2017, Chargoo \& Mareggi 2018, } \\
\text { idegaard et al. 2018 }\end{array}$ \\
\end{tabular}

The third concept, relational temporality in culture-led urban regeneration, illustrates local social time of traditions and activities. This concept reflects everyday life with work and leisure patterns. Relational temporality illustrates the urban via daily and weekly usage patterns. Urban rhythms, whether natural, cultural or spatial (Charbgoo \& Mareggi 2018), describe the local temporal context. Social and historical relationships affect local relational temporalities, 
making time a social phenomenon (Madanipour 2017). The mundane and ordinary establishes the values of relational time. While flagship buildings and big events stress visibility, in relational temporality, everyday life builds a basis for urban transformations. Relational culture-led urban regeneration encompasses leisure time via acknowledged elements such as evening economy, third places and consumption possibilities (Montgomery 1994, 2003; Charbgoo \& Mareggi 2018, Lidegaard et al. 2018) and weekday work-life patterns through minor cultural activities, education providers and cultural production (Montgomery 2003, Gainza 2017, Rahbarianyazd \& Doratli 2017). The activity of cultural quarters comprises the patterns in opening hours and existing local amenities, public space and land uses, variety of uses and temporal reach as well as festivals and events (Montgomery 2003). Table 1 demonstrates the qualities of the three temporal concepts and places them in relation with the concerned neighbourhood elements.

\section{Materials and methods}

The article constructs an empirical case study (Bryman 2015, Yin 2009). The main data for this study consists of eighteen individual, semi-structured long interviews with seventeen experts. I identified key stakeholders with chain referral sampling, where interviewees proposed further contacts during the process. The interview partners' affiliation ranged from municipal organisations, including urban planning department, event management, BusinessOulu (city-owned enterprise), local government, department of culture and museums, to private companies, real estate development, cultural organisations and other NGOs.

The selection of interviewees followed their central role in the study area. The questions focused on the regeneration process of the area and the role of culture within it. The sample pursues a balance between top-down and bottom-up urban development, as well as the interviewees' expertise on built environment, cultural realm, community initiatives, local politics and real estate. The citations provide anonymity to the interviewees, and the data excerpts in this paper refer to interviewees' expertise. Except for one pilot interview in 2014, the interviews were conducted in 2015-2017, and were accordingly tape-recorded, transcribed verbatim, coded and analysed.

In addition to the interviews, the empirical data set and background information includes public space and local event observation material from different seasons and daytimes, photographs from on-site visits, municipal plans and maps, strategic policy documents, architecture competition materials, public discourse in regional newspapers (2007-2017) and advertisement material. All translations from Finnish language by the author. The analysis of all data follows a fourphase-method: establishing categories, coding the interviews according to this classification, conducting an in-depth case analysis and exchanging between the data and prior theoretical knowledge (Schmidt 2004). The analysis builds upon three theory-driven temporal categories, iteratively reflecting the themes emerged from empirical data.

\section{Culture-led urban regeneration in Myllytulli}

Oulu, with its 200.000 inhabitants, locates on northern Ostrobothnia coast. The city district Myllytulli, an old industrial area, borders central Oulu in south and Oulujoki River Delta in north and west. Hupisaaret Islands Park covers half the neighborhood. Several cultural amenities, including Oulu Museum of Arts, Tietomaa Science Center and Oulu summertime theatre, as well as vocational school campuses, international elementary school and other educational facilities situate in Myllytulli. Lasaretinväylä waterway crosses the district at the interface between the park and built environment, where the key cultural amenities as well as the former Åström factory buildings are located. The southern part of Myllytulli 
is mostly residential. The young stakeholders, schoolchildren and students, characterise Myllytulli but also Oulu, which is Finland's youngest city by median age. Myllytulli's central location, preserved architectural heritage, cultural amenities and large recreational area Hupisaaret make the district important for travel and tourism.

The fast-flowing Oulujoki river delta with its mills shared their name with the district Myllytulli ('mylly' is the Finnish word for mill). In the 1800s, the delta area was turned into a park, 'Hupisaaret', following contemporary ideals for recreation. In late 1800 s, brothers Åström established a leather factory in delta area, which soon became the largest in Finland, transforming Myllytulli area into a contemporary industrial milieu. The municipality of Oulu constructed the first hydropower plant in early 1900s in Lasaretinväylä, serving both the community and the factory. By 1960s, the leather factory and hydropower plant closed down.

Image 2. Myllytulli district illustrated in an urban plan and an aerial picture. Oulujoki river delta characterizes the location and creates a northern border to the district. Base map (c) City of Oulu 2020, edited by the author.
The key industrial buildings have remained in Myllytulli, currently housing museums and offices. Lasaretinväylä's 'Old Factory', the former hydropower plant from 1903, and its adjoined buildings represent architectural heritage of regional importance (Salmela \& Eskelinen 1993). The 'Old Factory' served long as arts classroom for the nearby school. As the school left, the abandoned Lasaretinväylä factory milieu became a stage for underground culture scene and graffiti art (personal interview, community initiator, 2015).
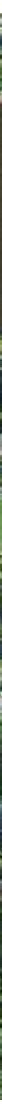

In 2006, a big fire damaged 'Old Factory'. Shortly thereafter, municipality of Oulu started mapping urban regeneration of Lasaretinväylä in 2008 through an architectural competition. In 2013, BusinessOulu requested an endeavour to generate a 'local actor network of creatives' and an 'innovation environment' in Myllytulli (personal interview, community initiator, 2015). The municipal urban planning department visualised the future urban regeneration ideals in the overarching strategy for physical urban development 'Myllytullivisio' (2017). Both the municipality and BusinessOulu regarded Myllytulli as a pilot for culture-led urban regeneration: "This process has combined tourism and culture with urban 
development as one of the first (in Oulu)." (Personal interview, cultural administration, 2017).

In Myllytulli, "there is the usual commercial urban development scheme, rezoning plots into residential area. --- Further, the strong cultural institutions under development --- Science Centre, Oulu Art Museum and Northern Ostrobothnia Museum. --- It is comparable to, conceptually, MuseumsQuartier Wien, a district for art and culture. Only less dense. There are collaborating cultural facilities. There is Ainola Park (Hupisaaret) with non-governmental initiatives and urban activism. And yet, there is Lasaretinväylä competition site, --- where (municipality) pursued trading permission to build apartment buildings against investment in common good." (Personal interview, cultural administration, 2017)

This article focuses on the culture-led urban regeneration process in Myllytulli 2008-2018. The municipal project focused on Lasaretinväylä, but the cultural clustering reaches around the district. The study includes urban regeneration initiatives in Myllytulli within the timeframe, but excludes any projects or processes without clear reference to arts or culture. The paper questions the temporal compatibility of suggested cultural amenities within the temporal context of the district. The following chapters illuminate Myllytulli culture-led urban

Table 2. The key interventions of Myllytulli culture-led urban regeneration process, illustrated within the temporal triad. Source: author. regeneration process via the three key categories of linear, experiential and relational development. Table 2 collects the discourse on Myllytulli culture-led urban regeneration process within the three temporal concepts, illustrating the relevance of different development modes.

$\begin{array}{lll}\begin{array}{l}\text { Temporal } \\ \text { category }\end{array} & \text { Executed interventions within the culture-led } & \begin{array}{l}\text { The role and effects of culture in the } \\ \text { urban regeneration process }\end{array}\end{array}$

\begin{tabular}{|c|c|c|}
\hline Linear & $\begin{array}{l}\text { Architectural competition and rezoning plan for } \\
\text { Lasaretinväylä; Prunnitori event plaza; } \\
\text { Renovating the 'Old Factory' buildings; } \\
\text { Constructing a student housing building and } \\
\text { apartments; Myllytullivisio overarching strategy } \\
\text { for physical urban development; building a } \\
\text { children's playground }\end{array}$ & $\begin{array}{l}\text { Representation as cultural district: } \\
\text { highlighting the architectural heritage; } \\
\text { attracting new residents; enabling } \\
\text { social gatherings in public spaces; } \\
\text { enabling cultural events through } \\
\text { rezoning to event venues and public } \\
\text { spaces }\end{array}$ \\
\hline Experiential & $\begin{array}{l}\text { Summertime temporary gardens and 'Rapumaja' } \\
\text { culture cottage from Dodo environmental } \\
\text { organisation; Established events including } \\
\text { annual EloJazz music festival, Flea Market Days, } \\
\text { annual Oulu Night of the Arts and Lumo light } \\
\text { festival }\end{array}$ & $\begin{array}{l}\text { Contents for the events; visibility; } \\
\text { media publicity; attractiveness, sense } \\
\text { of belonging, image building; } \\
\text { indicating places for culture, activity } \\
\text { and events; bundling events to gain } \\
\text { visitors }\end{array}$ \\
\hline
\end{tabular}

BusinessOulu project 'local actor network of creatives' and an 'innovation environment' in

Relational Myllytulli; initial municipal funding for cultural cluster in Lasaretinväylä; three established restaurants

\section{Linear culture-led urban regeneration process}

The municipal urban planning department dominated the linear culture-led urban regeneration process with following key phases: Lasaretinväylä competition call (2008), proposals for the call and announcement of the winning bid (2008), rezoning plan for Lasaretinväylä (2011) and execution (from 2011 onwards, still ongoing in 2019). This linear regeneration represents a top-down process with a limited amount of actors, the most important being municipal departments of urban planning and culture, while local cultural actors in Myllytulli were secondary in this process, developer company Hartela included with varying proportions. 
Municipality of Oulu had three main goals for the project: first, generating a physical cultural cluster with synergies to Myllytulli's existing cultural amenities; second, preserving and regenerating local architectural heritage; and third, establishing public spaces and opening the area physically to the locals. Both municipal cultural administration and non-governmental cultural actors pursues improving the prerequisites for cultural activity, whereas the winning developer wished to gain profits with construction business. This chapter elaborates the key objectives: physical cultural clustering, renovating architectural heritage and creating public space.

The competition area for the composite culture-led urban regeneration competition of Lasaretinväylä (2008) followed the waterway from Åström Park until Oulu Art Museum. The call sought composite ideas of construction schemes with architectural design and collaboration with cultural actors, resulting in seven proposals. The winning bid comprised of an 'Art Hall' in renovated 'Old Factory', central public space 'Event Plaza', an artisanal cluster in Sahasaari Island; three new, private residential buildings, student housing, and an elderly-care facility. Development company Hartela offered financial security, making their proposal the most attractive for the municipality, who wished no financial responsibility in the process. The physical closeness to municipal museums and key buildings, such as Oulu Art Museum, influenced the competition call (2008) and rezoning plan (2011), both of which included a mixture of cultural amenities, evening venues, galleries and artist residents. Lasaretinväylä area "should affiliate with the surrounding chain of culture, art and tourism" (rezoning plan, 2011). The physical closeness should lead synergy benefits. "This location, next to the Hupisaaret recreational area, close to the city center. There are cultural actors and others. I would wonder if it did not work." (Personal interview, urban planner,

Image 3. A children's playground in Hupisaaret Park. In the back, new residential development of Lasaretinväylä competition site. Photo source: author. 2015) However, the cultural clustering was mostly unsuccessful. Involved cultural actors withdraw the project when municipal financing ended, and Hartela found few substitute producers. The stakeholders were frustrated. "The competition proved unsuitable for this case. The conditions were too loose. --- There was no

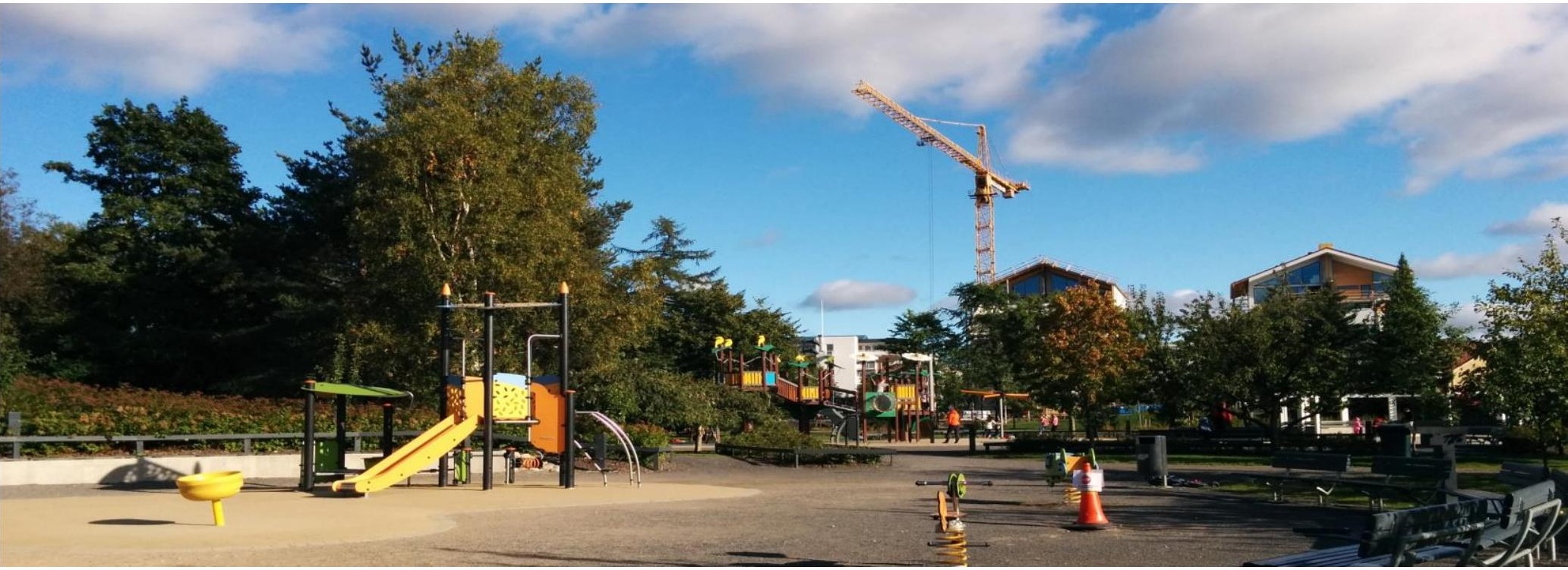

support' (personal interview, community initiator, 2015). Of all the cultural facilities proposed, by 2019 , only two restaurants and one small event venue have succeeded. "The competition was hastily organised, without control on the process --- no-one seemed responsible" (personal interview, cultural actor, 2015).

The existing cultural heritage offered advantageous prerequisites for urban regeneration. The former leather factory buildings create a recognisable unity. Through culture, municipality pursued visibility. "Everything is already there, 
Image 4. Lasaretinväylä waterway with new high-end apartments. At the end of the waterway, 'Old Factory' from 1903. Oulu city centre with Dome Church on the background. Photo source: author. someone should just say it aloud" (personal interview, cultural actor, 2015). Generally, historical structures strengthen collective memories and quality of places (Gehl 2011). Places with memorable narratives have stronger place identities, local knowledgeability and senses of history (Montgomery 2003). In culture-led urban regeneration, architectural heritage is expected to boost tourism (Evans 2009) and create a recognizable place brand (Bell \& Jayne 2004). The municipal planning department included the existing heritage buildings in main reasons for choosing culture as lead for the urban regeneration process. The existing buildings were in bad shape after fire damage in 'Old Factory' 2006. "The buildings were valuable, and the whole area (of Lasaretinväylä) was in state of abasement. Sahasaari had served as a parking lot for ages. And yet, the location was central' (personal interview, urban planner, 2015). The regeneration process maintained the valuable buildings, but they never became open to public, even 'Old Factory' turned private offices.

The municipal urban planning department pursued opening the area physically to public, including all the ground floors of heritage buildings. "There were interesting places --- but they were closed. People could not reach them" (personal interview, urban planner, 2015). The public spaces were designed within the planned cultural amenities. Public space enables social gatherings for everybody (Gehl 2011). Prior to the competition call, Lasaretinväylä "area was blocked. That (bad) condition --- made our objectives clearer: we wanted public spaces, open access. Our consultant would argue that fences are necessary around apartments but we remained strict on our opinion: only security-related fences, otherwise the area should be open to citizens" (personal interview, urban planner, 2015). By 2019, Sahasaari Island remains empty and 'Old Factory' is closed from public. Although new residents represent potential customers for the

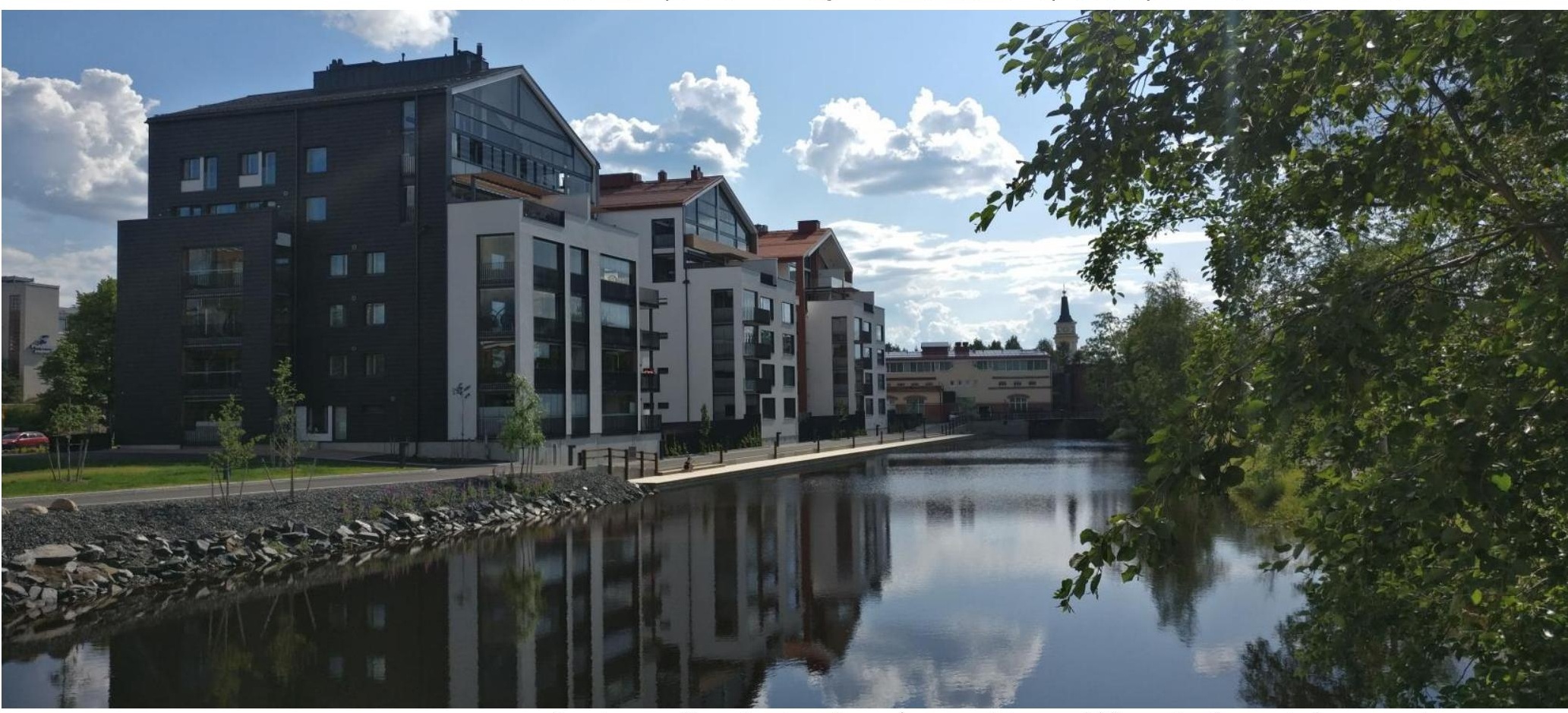

cultural amenities, the location of car parking and 'Prunnitori' event plaza creates confrontation, as "the residents wish no party on their own parking lot. Here, the values diverge" (personal interview, cultural administration, 2017), underground parking ramp dominates the new public space, 'Prunnitori' event plaza in front of the 'Old Factory'.

The northern climate implies context-specific functions for the public space. "In the Nordic environment, with the varying weather conditions, more (activities) take place indoors" (personal interview, cultural administration, 2017). The harsh 
climate makes organisation of outdoor events challenging. Thus, municipality of Oulu regards new construction as dominating tool for culture-led urban regeneration. "Municipal units passed their responsibilities to others: the department for culture and education, in my opinion, appealed to the department of urban planning, that they should, that there should be a building" (personal interview, community initiator, 2015). Both units ensured the importance of one another. "Urban planning, if we talk about attractive urban environments in general, is one of the key partners (of culture and education). The (cultural) contents intertwine with spaces and with areas" (personal interview, cultural administration, 2017).

\section{Experiential culture-led urban regeneration process}

Due to the dominating role of urban planning department, the importance of temporary uses (Madanipour 2017, Lehtovuori et al. 2003) or cultural events (Richards \& Palmer 2010) has remained rather small scale in Myllytulli's cultureled urban regeneration process. There are numerous small initiatives but the local stakeholder awareness of them is insufficient. "There is so much going on here and the residents are completely unaware of it --- but currently, it is standing still --- which is alarming" (personal interview, cultural actor, 2015). The actor constellation for experiential temporality is varied and diverse by nature. In experiential urbanism, the momentary and the weak influence the space production (Lehtovuori 2010). Prior to the urban regeneration project, Lasaretinväylä included Oulu's most interesting graffiti art, and after the 'Old Factory' fire, the site turned into 'trash galleries' reusing local resources for visuals arts. However, "underground is too underground" (personal interview, cultural administration, 2017) to become urban culture in Oulu. In Myllytulli, even the creative network tended to seek a top-down development mode for image building: "The task was to generate a brand for the local actors, which we found an outdated idea: having an extern consultant give the locals a new face" (personal interview, community initiator, 2015).

Image 5. Lumo Light festival 2019 in Hupisaaret park and elsewhere in Myllytulli district. Photo source: author.

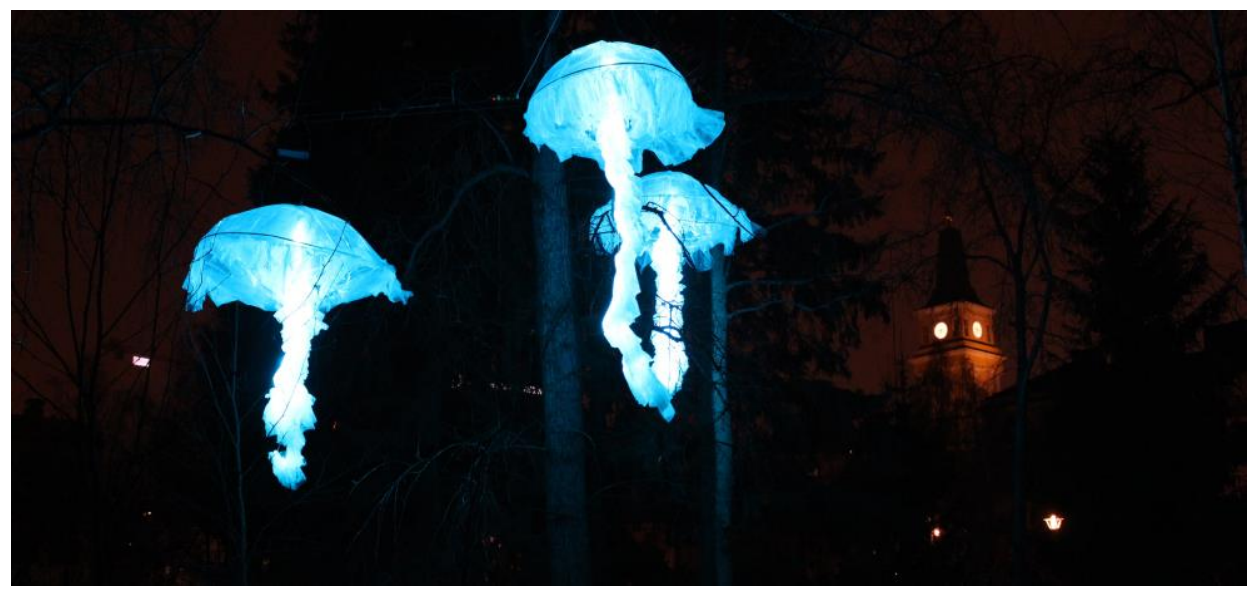

In the city of Oulu, event-led regeneration has slowly gained ground, adding events and 'eventfulness' (Richards \& Palmer 2010) in municipal cultural politics, urban development and urban regeneration. "The idea of an eventful city has gained interest and excitement here" (personal interview, cultural administration, 2017). For instance, the current 'program for architectural politics' (arkkitehtuuripoliittinen ohjelma, 2017) emphasises the relevance of events and culture for urban regeneration. Further, 'program for urban culture' (kaupunkikulttuurin toimenpideohjelma, 2013, 2018) and 'spatial plan for experiences' (elämysten kaava, 2015) discuss the contribution of culture to urban regeneration in Oulu. "In the big picture, urban culture relates to attractiveness, sense of belonging, and image" (personal interview, cultural administration, 2017). The established events in Myllytulli include EloJazz music festival, Flea 
Market Days, Oulu Night of the Arts and Lumo light festival. Hupisaaret has become a popular picnic stop for summers. Events are crucial for Myllytulli, located aside from city centre. For instance, Oulu Art Museum received the usual of three months visitors during only two days of the 2019 Lumo light festival.

Several cultural actors, especially the BusinessOulu 'creative networks' project attempted to create temporary uses in Myllytulli, but there was a lack of interest from the municipal site. "There are no empty industrial halls where culture would be allowed, due to their bad condition --- (A re-use) would require public subvention" (personal interview, cultural administration, 2017). Regarding new initiatives, "there is a lack of know-how and resilience (in Oulu)" (personal interview, cultural administration, 2017), from both the municipal and the stakeholder side. For the private sector, economic profit lies within security rather than allowing pop-up uses (personal interview, local politician, 2017). Dodo environmental organisation managed to find their spot in Myllytulli. Dodos 'Rapumaja' comprises a small cottage and surrounding summertime gardens for temporary use.

The temporal context in Oulu constructs the framework of possibilities to the event scene. Not only that "Oulu is rather small, so compared with Helsinki or Tampere, it is challenging to organise big concerts" (personal interview, cultural administration, 2017), but also, the smaller-scale, every-week event scene faces challenges. Social media has influenced on-site behaviour and partly desolated Image 6. Hupisaaret in winter. and cyclists follows Lasaretinväylä waterway. Sahasaari on the right. Photo source: author. the public space: "If nothing happens, it is no more fatal. You can be social in the internet" (Personal interview, cultural administration, 2017). This context requires cultural event organisers to create temporal densification, in order to gain a

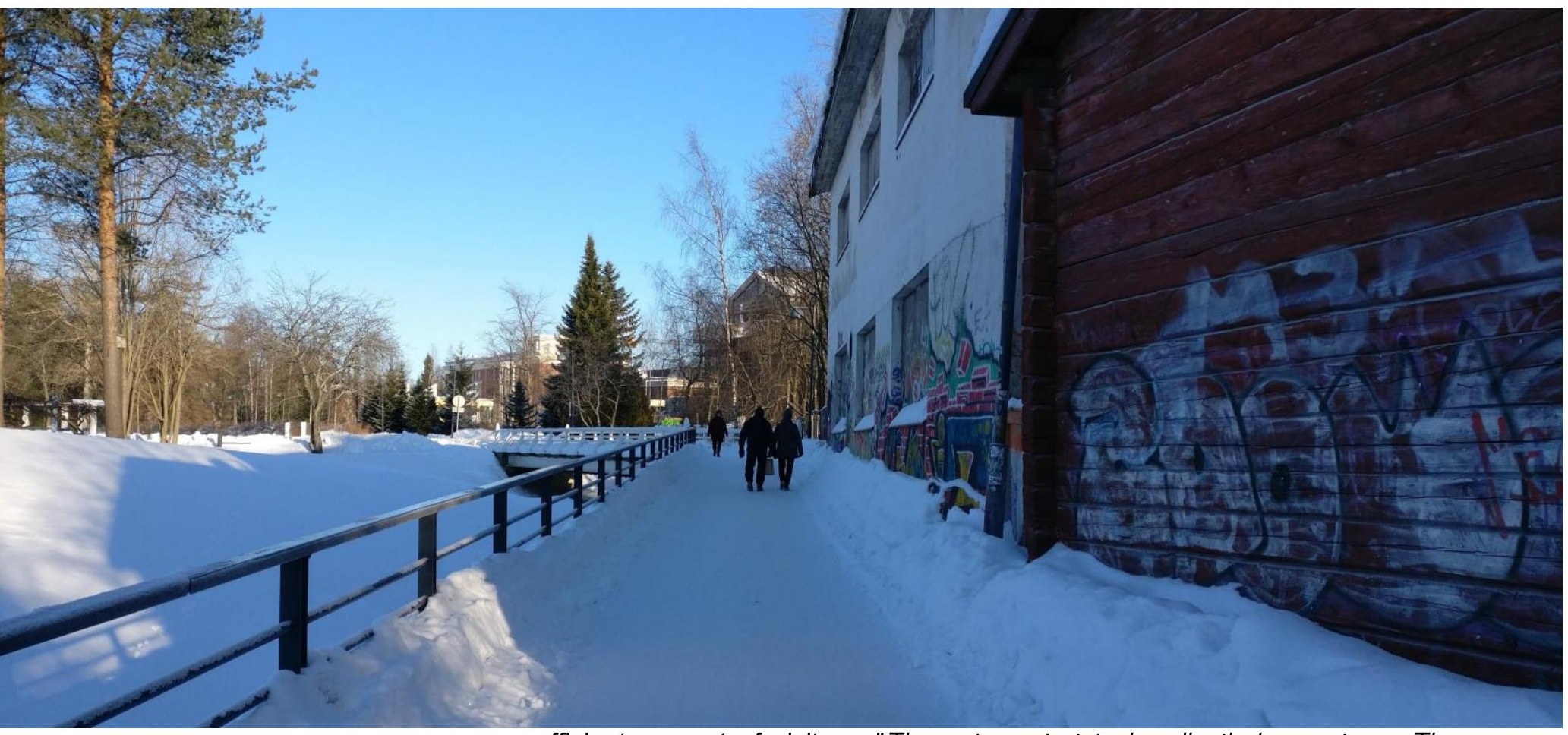

sufficient amount of visitors. "The actors start to bundle their events --- The openings are organised on the same day, so people will go out. Go around, take place. It causes densifications. In the lived, in the event scene" (Personal interview, cultural actor, 2017). Culture creates visibility: "I prefer events to pinpoint the places, rather than having fixed places, where events should appear" (Personal interview, cultural actor, 2017). 


\section{Relational culture-led urban regeneration process}

Relational culture-led urban regeneration concerns leisure time on the one hand, and weekday time patterns on the other hand. Academic discourse recognises several elements that relate to leisure time, such as evening economy, third places and consumption possibilities (Montgomery 1994, 2003; Charbgoo \& Mareggi 2018, Lidegaard et al. 2018); whereas minor activities, education providers and cultural production (Montgomery 2003, Gainza 2017, Rahbarianyazd \& Doratli 2017) relate to weekday work-life patterns. The actor networks of relational urban regeneration are heterogenous and varying, depending on the time of the day and year. Here, environmental temporalities (Degen 2018), such as natural rhythms (Charbgoo \& Mareggi 2018), play a significant role.

Myllytulli differs from neighbouring districts through its relational time use patterns. Where central Oulu depicts a mixed-use environment with commerce and apartments, offices and administrative uses, Myllytulli accommodates significant public buildings, educational facilities and municipal museums. The public and educational buildings in Myllytulli indicate rigid opening hours but also long evening and summertime vacancies. The office hours 8-to-16 are busy in the district, but evenings involve few activities. The numerous education providers affect the rhythms of Myllytulli. In central Oulu, the businesses and shops have long opening hours, and night-life flourishes, but the educational district closes its curtains, when schoolchildren go home, or at latest, when the sun goes down. "The ancient cycles of agrarian society still rhythm our contemporary society. Compared with the rest of Europe, our summer season is relatively long (in Finland), and part of our city is stagnated, and empty" (Personal interview, local politician, 2017). The existing municipal museums close at 18 , also on weekends. Involved cultural actors expressed their frustration. "Is this supposed to be a cultural district - there is a municipal art museum, but is there anything else?' (Personal interview, community initiator, 2015)

Image 7. Elojazz festival guests in Åström Park. Rauhala restaurant on the background. Photo source: author.

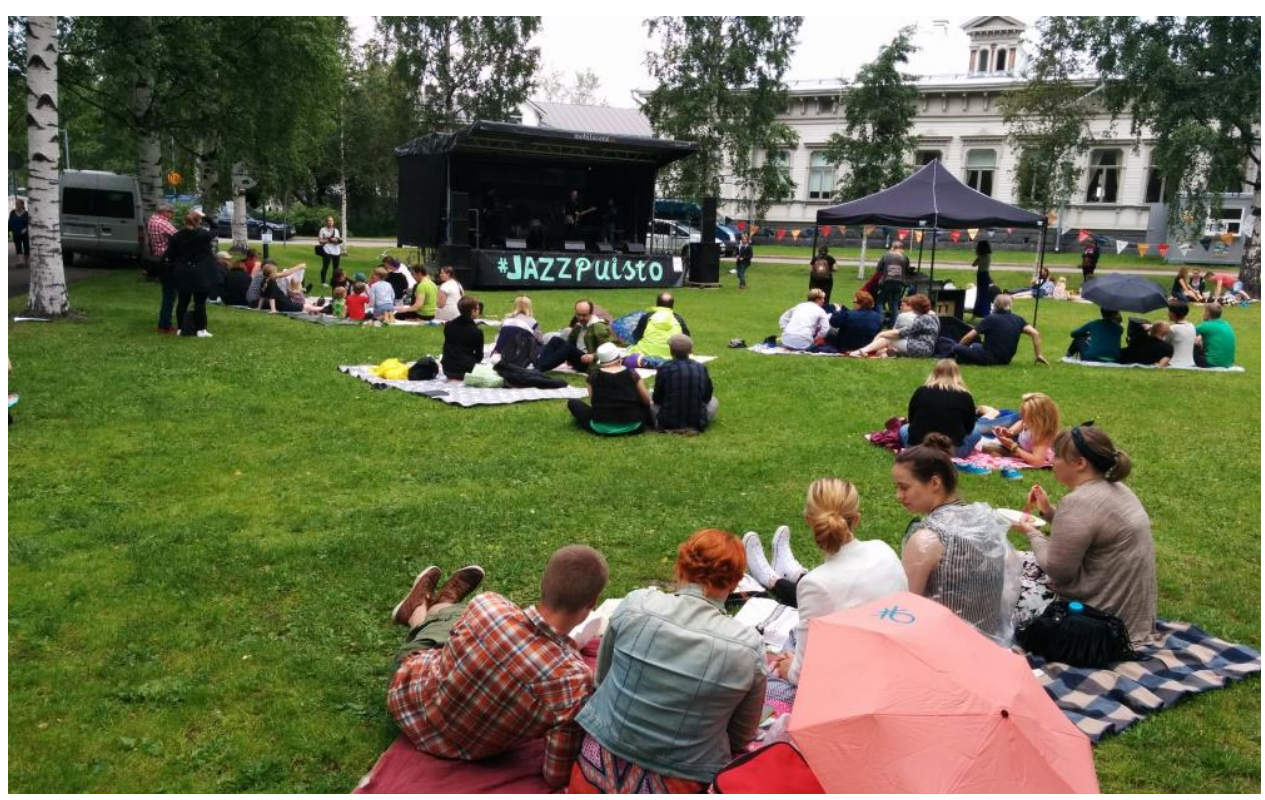

Leisure area Hupisaaret Park and enclosing Oulujoki River delta, which follow natural rhythms, cover half of Myllytulli. The northern location of Oulu translates to scarce winter daylight and long bright summer nights. The children's playground and Hupisaaret Park is most popular in daylight time. The huge difference in sunlight and temperature within seasons restricts the use of Hupisaaret Park throughout the year. Especially vulnerable groups, children and elderly, suffer from lack of light and extreme winter temperatures, which might 
drop as low as $-30 \mathrm{C}$ in Oulu. There are few consumption possibilities in the district. Here, restaurant Tuba succeeded well in integrating locals and tourists. They cooperate with other events in Myllytulli, including daytime occasions, such as 'Restaurant Day' and 'Flea Market Day', or Elojazz, on long summer nights of Oulu. The popularity of Tuba demonstrates how crucial it is to embrace the local time use patterns, like the hungry families from playground. The idea of the municipality to create a 'cultural cluster' is valuable but possibly the type of cluster was inappropriate. The 'high arts' of Oulu Art Museum remain distant from the routine, every weekday or weekend leisure uses. The very everyday of Myllytulli consists of the schoolchildren, teenagers and students learning; people working and travelling home, moving on foot and by bike; families and students relaxing at Hupisaaret Park. The project neglected the existing user groups and there was no activity provided for the cyclist community.

The municipal culture-led urban regeneration project concentrated on cultural economies, largely incompatible with Myllytulli. The culture and leisure amenities should relate to the everyday life of the locality. The regeneration project neglected the families and young parents active in Myllytulli. "Our feedback states that, parents wish activities for the time where their children have their hobbies. There is an existing demand' (Personal interview, community initiator, 2015). Within the city of Oulu, children's culture is gaining interest and respect, but they were missing within Myllytulli's culture-led urban regeneration process. There is a need for both will for cooperation and new tools for coping with social time. "Generally, the urban planning department would only mind their main tasks --Our (networking) project should not intervene with the rezoning process" (Personal interview, community initiator, 2015). The municipal urban regeneration project failed to appreciate the existing social assets, such as children and families, mundane and everyday uses, or the cycle traffic through the recreational area.

Relational time in urban regeneration necessitates all stakeholders to accept the complexity of the process
Social time is most important temporal category for sustainable and continuous cultural activities in regenerated areas. "I would not worry about individual showcase projects in Oulu, but rather the everyday urban culture, it is much more important" (personal interview, cultural administration, 2017). Even if there is a permanent cultural facility, it only "offers the walls, but the program will decide, what will happen" (personal interview, cultural administration, 2017). "It depends on the uses (rather than the physical building), if it will work" (Personal interview, community initiator, 2015).

Relational time in urban regeneration necessitates all stakeholders to accept the complexity of the process. "The discourse is still missing (here). If we really want to navigate the different (opinions). We write urban strategies, where there is hustle and bustle. But: how to do it? It is still missing. The only way to do it is, to offer prospects for the different stakeholders. To find --- compromises and solutions. --- The current discourse seems to avoid all conflict. If anyone has anything against anything, the discussion comes to an end" (personal interview, cultural actor, 2017).

Relational temporality is key to culture-led urban regeneration, but it is also difficult to implement due to its complexity. There are no existing tools for municipal officials to combine with social time and urban regeneration. "The urban planning processes are have a certain form and solidity, so it takes time for the 'soft' and 'hard' aspects, as I call them, to integrate" (personal interview, cultural administration, 2017). Relational temporality signifies the process of moving from ephemeral to continuity, repeating activities enable the required social networks. 


\section{Discussion}

This study identified all three temporalities with varying emphasis in Myllytulli's culture-led urban regeneration process. The municipal viewpoint follows the linear ideals; the local community depicts relational temporality, whereas individual experiences remain personal and various. The temporal analysis revealed certain conflicts between these three approaches. The municipality yet dominates and controls the times of Myllytulli urban regeneration, while the role of experiences is growing of importance. However, relational time remains challenging for urban planners due to its complexity (see also Lehtovuori 2010). Cultural actors of Myllytulli acknowledged all three temporalities as present in district arts-led regeneration processes: 'the systematics between temporary street art, permanent public art, and art happening on the streets create a trinity' (personal interview, cultural administration, 2017).

This study demonstrated how the different temporal approaches affected Myllytulli's culture-led urban regeneration process. This analysis separates the activity within the three modes, but a successful cultural district indicates a balance between activity and built form (Lynch 1981). Thus, such a categorization

Image 8. Despite the efforts of municipal planning department to generate public space in Lasaretinväylä, in the heart of Myllytulli, the location of new residential buildings between Oulu Museum of Arts and 'Old Factory' and 'Prunnitori' event plaza expose conflicting interests. The sign states: "PRIVATE PROPERTY. No trespassing." Photo source: author. offers potential for a theoretical endeavor, whereas practical applications for urban planning and local development require a more holistic approach. Furthermore, a single case study remains yet limited in its potential to draw general conclusions even for similar contexts. A further exploration of provincial cities and other small city contexts could enable suitable theoretical concepts. Oulu is remotely located in northern Finland and its natural-temporal context poses restrictions to cultural activity in Myllytulli, restraining outdoor activities to certain seasons or daytimes. Distant regions as cultural locations require further research (see also Salone et al. 2017).

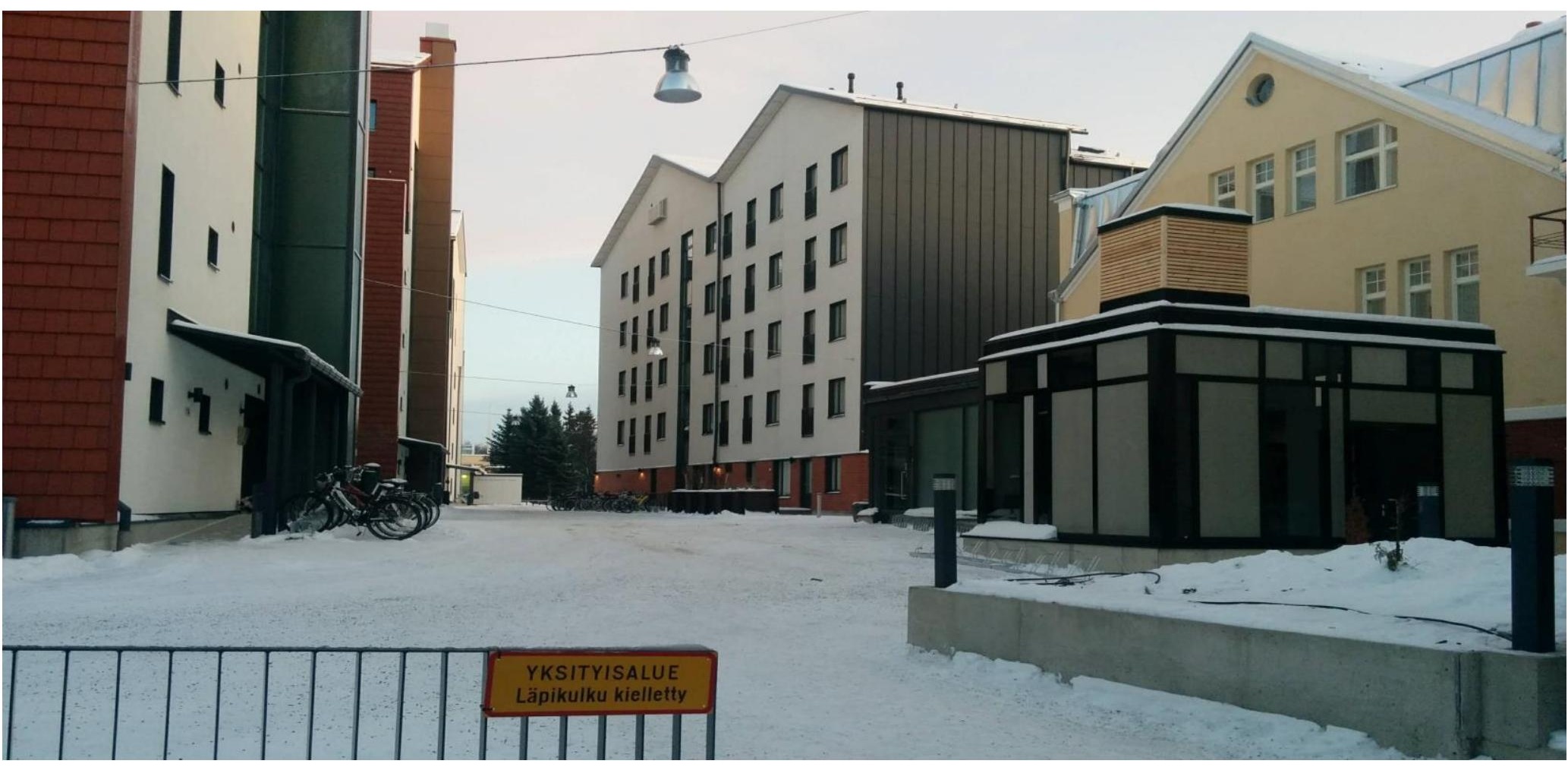

As small cities borrow their culture-led policies from contexts of cultural metropolises, they tend to obtain the metropolitan definition of 'culture' as well, even though there is much more to culture in smaller localities than the usual 'creative industries'. The BusinessOulu networking project pursued supporting local creative enterprises even though those were few in the district. The global 
As small cities borrow their cultureled policies from contexts of cultural metropolises, they tend to obtain the metropolitan definition of 'culture' as well, even though there is much more to culture in smaller localities than the usual 'creative industries' culture-led models come from metropolises, accordingly the target group for planned cultural amenities: 'creative class'. However, Myllytulli's temporal context consists of community of children, families, cyclists instead of metropolitan creatives. The case Myllytulli demonstrates how important it is to consider the local temporal context within culture-led urban regeneration. While culture has become a global buzzword to create visibility and interest, its key potential lies within locality. In order to support long-lasting and resilient culture-led urban regeneration, culture should derive from and develop in accordance with local everyday life.

Evening economy's relevance for culture-led urban regeneration is smaller in provincial or smaller cities, where young families and children's culture compose the urban cultural landscape. Local stakeholders' timetables support the everyday community cultures. Targeting existing stakeholders instead of tourists not only strengthens the local economy, culture and community, but also, enables successful events and activities altogether by keeping the visitor count stable. The certain underestimation of children's culture in Myllytulli possibly complicated the process altogether. The recently constructed children's playground in Hupisaaret Park is located separately from Myllytulli's urban public spaces, municipal museums and the architectural competition site of Lasaretinväylä. Even the competition program for culture-led urban regeneration sought a cluster with municipal museums, and excluded Hupisaaret and Myllytulli's educational facilities from 'cultural amenities'.

Thus, the endeavour to establish a vivid evening economy represents a cultureled urban regeneration objective borrowed from global metropolises. Provincial cities need to find individual ways to regenerate cultural districts without existing models. The local cultural actors found Oulu's temporal context problematic. "The scale of this city poses challenges (to urban regeneration)" (personal interview, community initiator, 2015). Even the local actors wished for easy examples and convenient models for culture-led urban regeneration, although culture is placespecific and fragile, especially when borrowed. "There is so much potential in these (culture-led urban regeneration) models. But for cities intermediate in size, I would say Oulu lies in this category, the tools should be so different. I don't know --- what those tools are." (Personal interview, community initiator, 2015).

In provincial cities, the timing of events and activities is of crucial importance. Cultural actors in Myllytulli bundled their events in order to encourage enough visitors on-site. In smaller cities, where the cultural attendance is scarce and visitor counts remain low, finding correct time slots for social gatherings becomes vital for cultural activity. This also relates to the long distances of peripheral contexts and long commutes. Therefore, it is important to revise cultural timetables.

\section{Conclusions}

The future studies of culture-led urban regeneration should include the notion of temporality to their research settings, as temporality reveals underlying issues of local social and spatial aspects. Time facilitates a tool of analysis for the planners, planning instruments to complement the spatially oriented blueprint plan but also a way of exploring and experimenting the urban space in a flexible and affordable way. Temporal experiments with small initial investments would allow a wider comprehension on the local usage patterns. Inclusion as key, not economy, to concentrate on the everyday of the locals rather than initiating cultural destinations for the tourists. Coordinating time in the society would bring further benefits than to the cultural scene - for instance, harmonizing the urban life would ease the flows of people and traffic. 
This study illustrates the hitherto uncharted temporal specifics of smaller cities, demonstrating how their urban cultures and temporalities differ from metropolitan contexts. This study represents yet an initial exploration in this topic, which would require further theoretical exploration and empirical research. Major cities dominate academic discourse, and further studies should aim at revising the bias of metropolitan areas and culture-led urban regeneration. Temporal intensification (Palva 2017) and 24-hour cities (Montgomery 1994) are phenomena connected to metropolitan contexts. It is crucial to explore time planning (Moccia 2000) in the context of smaller cities and create new theoretical concepts.

\section{Acknowledgements}

Author would like to thank all interviewees, reviewers and editors, as well as Prof. Helka-Liisa Hentilä, Prof. Andreas Voigt and Dr. Sari Hirvonen-Kantola for their helpful comments and overall support.

\section{Funding Statement}

University of Oulu Graduate School has enabled conducting this study.

\section{Disclosure Statement}

Author does not have any financial interest or benefit arising from the direct applications of this work.

\section{References}

Andres, L. (2013) Differential spaces, power hierarchy and collaborative planning: a critique of the role of temporary uses in shaping and making places, Urban Studies, 50(4), 759-775.

Bell, D., \& Jayne, M. (2004). Conceptualizing the city of quarters. In Jayne, M. (Ed.) City of quarters: Urban villages in the contemporary city, 1-12.

Bell, D., \& Jayne, M. (2006). Conceptualizing small cities. In Bell, D. \& Jayne, M. (Eds.) Small Cities: urban experience beyond the metropolis. (pp. 15-32). Routledge.

Bell, D., \& Jayne, M. (2009). Small cities? Towards a research agenda. International Journal of Urban and Regional Research, 33(3), 683-699.

Bianchini, F. (1993). Remaking European cities: the role of cultural policies. In Bianchini, F. \& Parkinson, M. (Eds.) Cultural policy and urban regeneration: The West European experience, 1-20.

Bryman, A. (2015). Social research methods. Oxford university press.

Charbgoo, N., \& Mareggi, M. (2018). A framework for time studies in urban planning: Assessment of comprehensive planning in the case of Tehran. Environment and Planning B: Urban Analytics and City Science, 2399808318821118.

Cho, R. L., Liu, J. S., \& Ho, M. H. C. (2018). What are the concerns? Looking back on 15 years of research in cultural and creative industries. International journal of cultural policy, 24(1), 25-44.

Deffner, A. M. (2005). The combination of cultural and time planning: a new direction for the future of European cities. City, 9(1), 125-141. 
Degen, M. (2018). Timescapes of urban change: The temporalities of regenerated streets. The Sociological Review, 0038026118771290.

Dodgshon, R. A. (2008). Geography's place in time. Geografiska Annaler: Series B, Human Geography, 90(1), 1-15.

Evans, G. (2002). Cultural planning: An urban renaissance?. Routledge.

Evans, G., \& Foord, J. (2006). Small cities for a small country: Sustaining the cultural renaissance?. In Bell, D. \& Jayne, M. (Eds.) Small Cities: urban experience beyond the metropolis. Routledge.

Evans, G. (2009). From cultural quarters to creative clusters-creative spaces in the new city economy. Stockholm: Institute of Urban History.

Florida, R. (2002). The rise of the creative class, and how it is transforming work, leisure, community and everyday life. New York.

Garcia, B. (2004). Cultural policy and urban regeneration in Western European cities: lessons from experience, prospects for the future. Local economy, 19(4), 312-326.

Garnham, N. (2005). From cultural to creative industries: An analysis of the implications of the "creative industries" approach to arts and media policy making in the United Kingdom. International journal of cultural policy, 11(1), 1529.

Gehl, J. (2011). Life between buildings: using public space. Island press.

Graham, S., \& Healey, P. (1999). Relational concepts of space and place: Issues for planning theory and practice. European planning studies, 7(5), 623646.

Henckel, D. (2007). Building high and running fast - Cities as Spaces and Time Saving Entities. In Henckel, D., \& Pahl-Weber, E. (Eds). Time space places, 59-74. Peter Lang GmbH.

Herkommer, B. (2007). Slow City - Fast City. An exploration into urban speed. In Henckel, D., \& Pahl-Weber, E. (Eds). Time space places, 37-58. Peter Lang $\mathrm{GmbH}$.

Jacobs, J. (1961). The death and life of great American cities. Harmondsworth : Penguin.

Lehtovuori, P.; Ruoppila, S. (2017). Temporary uses producing difference in contemporary urbanism. In Henneberry, J. (ed.) Transience and Permanence in Urban Development. John Wiley \& Sons Ltd.

Lehtovuori, P. (2010). Experience and conflict: The production of urban space. Routledge.

Lehtovuori, P.; Hentilä, H-L.; Bengs, C. (2003). Temporary uses: the forgotten resource of urban planning. Publications in the Centre for Urban and Regional Studies C 58 2003. Helsinki, Art-print Oy.

Lidegaard, C., Nuccio, M., \& Bille, T. (2018). Fostering and planning urban regeneration: the governance of cultural districts in Copenhagen. European Planning Studies, 26(1), 1-19. 
Lynch, K. (1981). A theory of good city form. MIT press.

Lynch, K. (1972). What time is this place? Mit Press.

Lysgård, H. K. (2012). Creativity, culture and urban strategies: A fallacy in cultural urban strategies. European Planning Studies, 20(8), 1281-1300.

Lysgård, H. K. (2016). The 'actually existing' cultural policy and culture-led strategies of rural places and small towns. Journal of Rural Studies, 44, 1-11.

Madanipour, A. (2017). Cities in time: Temporary urbanism and the future of the city. Bloomsbury Publishing.

Miles, M. (2005). Interruptions: Testing the rhetoric of culturally led urban development. Urban studies, 42(5-6), 889-911.

Miles, S. (2006). Small city-big ideas: culture-led regeneration and the consumption of place. Small cities: Urban experience beyond the metropolis, 233-243.

Miles, S., \& Paddison, R. (2005). Introduction: The rise and rise of culture-led urban regeneration. Urban Studies, Vol. 42, Nos 5/6, 833-839, May 2005.

Moccia, F. D. (2000). Planning time: an emergent European practice. European Planning Studies, 8(3), 367-375.

Montgomery, J. (2003). Cultural quarters as mechanisms for urban regeneration. Part 1: Conceptualising cultural quarters. Planning, Practice \& Research, 18(4), 293-306.

Montgomery, J. R. (1994) Planning for the night-time economy of cities, Regenerating Cities, 7(December), pp. 32-39.

Peck, J. (2005). Struggling with the creative class. International journal of urban and regional research, 29(4), 740-770.

Pine, B. J., \& Gilmore, J. H. (1998). Welcome to the experience economy. Harvard business review, 76, 97-105.

Raco, M., Henderson, S., \& Bowlby, S. (2008). Changing times, changing places: urban development and the politics of space-time. Environment and Planning A, 40(11), 2652-2673.

Rahbarianyazd, R., \& Doratli, N. (2017). Assessing the contribution of cultural agglomeration in urban regeneration through developing cultural strategies. European Planning Studies, 25(10), 1714-1733.

Richards, G., \& Palmer, R. (2010). Eventful Cities. Amsterdam: Routledge.

Richards, G., \& Wilson, J. (2006). Developing creativity in tourist experiences: A solution to the serial reproduction of culture?. Tourism management, 27(6), 1209-1223.

Roberts, P. \& Sykes, H.(Eds.). (2000). Urban regeneration. Sage.

Salmela, A., \& Eskelinen, O. (1993). Pohjois-Pohjanmaan kulttuurihistoriallisesti merkittävät kohteet. Osa 3. Oulaisten-Haapaveden seutukunta, Ylivieskan seutukunta, Haapajärven-Pyhäsalmen seutukunta. Pohjois-Pohjanmaan seutukaavaliitto, Oulu. Julkaisu A: 117. 151 s. ISBN 951-9328-55-6. 
Salone, C., Bonini Baraldi, S., \& Pazzola, G. (2017). Cultural production in peripheral urban spaces: lessons from Barriera, Turin (Italy). European Planning Studies, 25(12), 2117-2137.

Schmidt, C. (2004). The analysis of semi-structured interviews. In Flick, U., von Kardoff, E., \& Steinke, I. (Eds.). A companion to qualitative research, 253-258. Sage.

Yin, R. K. (2009). Case study research: Design and methods 4th ed. In United States: Library of Congress Cataloguing-in-Publication Data (Vol. 2).

Zukin, S. (1995). The cultures of cities. Wiley-Blackwell. 